\title{
C oastal zone of The G ambia and the Abidjan region in Côte d'Ivoire: sea level rise vulnerability, response strategies, and adaptation options
}

\author{
Bubu P. J allow ${ }^{1, *}$, Sekou Toure ${ }^{2, * *}$, Malang M. K. Barrow ${ }^{3}$, Assa Achy Mathieu ${ }^{4}$ \\ ${ }^{1}$ Department of Water Resources, 7 M arina Parade, Banjul, The G ambia \\ 2E cole Nationale Superieure des Travaux Publics, Yamoussoukro, C ôte d'Ivoire \\ ${ }^{3} \mathrm{~N}$ ational Environment Agency, 5 Fitzgerald Street, Banjul, The G ambia \\ ${ }^{4}$ Physics Department, University of Cocody, A bidjan, Côte d'Ivoire
}

\begin{abstract}
The aerial videotape-assisted vulnerability analysis (AVVA) technique was combined with various data sets to assess the vulnerability of the coastal zone of The Gambia to sea level rise. Land loss due to inundation, flooding, and erosion was estimated. Costs of damage and population at risk were also evaluated. Only historical data and maps were used to assess the vulnerability of the coastal zone of the Abidjan region of Côte d'Ivoire to sea level rise. Results show that with a $1 \mathrm{~m}$ sea level rise the whole of the capital city of Banjul will be under mean sea level in the next 50 to $60 \mathrm{yr}$ as a greater part of the city is below $1 \mathrm{~m}$. The mangrove systems on St. Mary's Island, Kombo St. M ary, and the strand plains in the north bank will be inundated. About 1950 billion Dalasis (US \$217 million) worth of land will be lost. The most appropriate response would be to protect the whole of the coastline of Banjul, the shoreline area from the Banjul cemeteries to Laguna Beach Hotel, the infrastructure at Sarro, and the hotel complex at Cape Point. Innovative sand management, repair of the damaged groins, and construction of dikes, breakwater structures, revetments, and low-cost seawall are some of the shoreline stabilization and hardening techniques suggested for the protection of this area. For the A bidjan region, the same response strategies should be used. Adaptation responses identified for both regions include public awareness, increase in height of coastal infrastructure, urban growth planning, wetland preservation and mitigation, and development of a coastal zone management plan.
\end{abstract}

KEY WORDS: Erosion · Inundation · Land loss · Mangroves · Vulnerability analysis · Bruun Rule

\section{INTRODUCTION AND BACKGROUND INFORMATION ON THE COASTAL ZONE}

The coastal zone of The Gambia extends $80 \mathrm{~km}$ from Buniadu Point and the Karenti Bolong in the north to the mouth of the Allahein River in the south (Fig. 1). It has $70 \mathrm{~km}$ of open ocean coast and about $200 \mathrm{~km}$ of sheltered coast along the River Gambia. The sheltered coast is dominated by extensive mangrove systems (66900 ha) and mud flats.

Only about $20 \mathrm{~km}$ of the coastline is significantly developed, and this includes Banjul (the capital city),

\footnotetext{
*E-mail: dwr@gamtel.gm

** Present address: High Commissioner for Hydraulics, Abidjan, Côte d'Ivoire
}

Bakau and Cape St. Mary, Fajara, and the Tourism Development Area (TDA). Thirteen hotels and tourist resorts have been built on this stretch of the coastline. Elsewhere, the coastline is largely underdeveloped, except for some fish landing sites and cold storage infrastructure used to process and store fish and shrimp. The coastal zone contributes significantly to the economy of The Gambia. From October to May, The Gambia receives more than 100000 tourists, all beach resorts and hotels are operational, and the industry employs about 7000 persons either directly or indirectly.

The region of Abidjan is situated in Southeast Côte d'Ivoire with a surface area of about $12180 \mathrm{~km}^{2}$ and is composed of the districts of A bidjan, Agboville, Tiassale, and Grand-Lahou. The population is over 2 mil- 


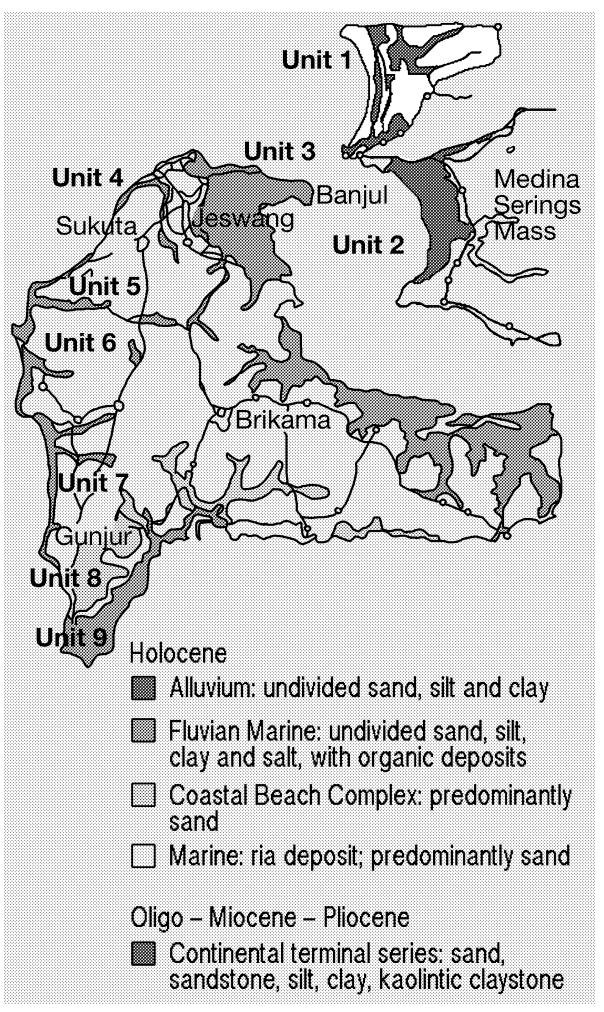

Fig. 1. Coastal zone of The Gambia

lion inhabitants, and the population density is high (80 persons $\mathrm{km}^{-2}$ ). Hydrologically, the region is drained by the Bandama River and other streams such as Ira and Agneby (Delor et al. 1992). In the east-west direction, the drainage is by Ebrie Lake, into which most small rivers empty. The climate of the Abidjan region is equatorial, having 2 rainy seasons separated by 2 dry seasons. Rainfall decreases in the south-to-north direction from 2100 to $1400 \mathrm{~mm}$ per annum. The variation in temperature is low, with fluctuations between 24 and $27^{\circ} \mathrm{C}$.

In this region lies the capital city of A bidjan, which is highly metropolitan. Important economic activities and infrastructure of the region include: (1) The establishment and management of vast rubber, pineapple, oil palm, and coconut plantations. (2) The Port of A bidjan, which provides facilities for trading with the rest of the world. Access to the ocean is provided by the Vridi Canal. (3) Ocean fisheries, which remain the main activity of the coastal population. (4) Important 4-lane highways, which run in the southeast-to-northwest direction. (5) Both national and international air transport provided at the Abidjan International Airport at Port Bouet.

The region can be divided into 3 geomorphologic units in a south-to-north direction. These are: (1) The shoreline linking the Atlantic Ocean with the main- land. This zone is composed mainly of lagoons and streams. (2) An intermediate zone with low relief. (3) The hinterland with relatively high altitudes of 50 to $200 \mathrm{~m}$.

\section{ASSESSMENT METHODOLOGY AND DATA USED IN THE ASSESSMENT}

2.1. Data sets. Various data sets for the coastal zone of The Gambia and the Abidjan region were assembled to inventory and characterize the study areas. The data and information collected included black-andwhite and colour infrared aerial photographs, and topographic, geological, and bathymetric maps of both study areas. Also available were contoured orthophoto maps of the 1982 aerial photography for the Gambian coastal zone. Still photographs from different years showing some of the damage caused by erosion were also available from the Oceanography Centre of Côte d'I voire and the Department of Water Resources of The Gambia.

Documentation of past similar studies was undertaken, and, to augment the data and information on the A bidjan study area, it was necessary to interview some people. Those interviewed included residents close to the coastline of A bidjan, contractors working for a project on the construction of a breakwater west of the Vridi Canal, the coastguards at the Vridi Canal, and some staff of the Oceanography Centre.

A low-level ( 150-200 m) video record of both the open and sheltered coasts of The Gambia was acquired, but due to logistics and time constraints, this was not possible in the Abidjan study. The video record was obtained as part of the aerial videotapeassisted vulnerability analysis (AVVA) technique (Leatherman et al. 1995). From the video record, it is possible to determine the type of coast, land use, land cover, and infrastructure.

Socio-economic data (GDP, GNP, and so forth), along with information on annual number of tourists and outof-pocket expenditures, fish landing and catch by species, wetland habitats, and historic and cultural assets, were also available. The Department of Physical Planning also made available the value of land along the coast.

2.2. Methodology. The impact assessment procedure used in both studies follows the AVVA technique and the IPCC Common Methodology, but it was not possible to conduct video recording of the Abidjan region. AVVA is a new, rapid, and low-cost technique that involves the combination of (1) obliquely videotaping the coastline at low altitude from a small airplane and (2) carrying out archival research (Leatherman et al. 1995). Combining the video record and the 
historical data, it was possible to assess, both qualitatively and quantitatively, some of the potential impacts of a $1 \mathrm{~m}$ sea level rise. The assessment involves the characterization of the study area, determination of sea level scenarios, estimation of land loss and other damage, translation of this damage to monetary terms, and identification of response strategies and adaptation options.

2.2.1. Characterization of the coastal zone: Based on the assembled data, it was possible to characterize the coastal zone of the 2 study areas. The coastal zone of The Gambia was characterized into the 9 units shown in Fig. 1. Each unit contains 1 or a combination of coastal types. A detailed description of these units is contained in Jallow et al. (1996). Some of the units are based on the UNEP/OCA PAC Report (Quelenec 1988). The coastal zone of the A bidjan region was characterized into 2 units: west and east of the Vridi Canal.

2.2.2. Sea level rise scenarios: Tide gauge records available for both study areas cover only a short period of time, and long-term geological data suggest insignificant tectonic variations. Hence, the global sea level rise scenarios that have been widely adopted in the IPCC documentation (IPCC 1990, Pepper et al. 1992) are used. These scenarios are the current rate of sea level rise of 0.2 (no acceleration), 0.5 , and $1.0 \mathrm{~m}$ century $^{-1}$. Where the variation of the land formation is relatively smooth, the $0.5 \mathrm{~m}$ contour of land inundation was interpolated from the $1.0 \mathrm{~m}$ contour line on the coastal map series.

2.2.3. Estimation of land loss and damage: Of primary concern is to determine how much land will be lost due to sea level rise. On the sheltered coasts and where the open coast is characterized by spits or barriers backed by marshes and mangroves and, in some places, strand plain type of coast, the drowning or permanent submergence (inundation) concept of land loss was used as the initial potential impact. After inundation, erosion of the open coast continues due to wave action, and the Bruun Rule is used to determine the retreat of the land.

The area likely to be inundated was delineated on the topographic maps by estimating the $1 \mathrm{~m}$ contour line. Land loss due to the lower $(0.2 \mathrm{~m})$ scenarios was estimated by linear interpolation from the amount of loss due to the $1 \mathrm{~m}$ sea level rise. The percentage loss for intermediate $(0.5 \mathrm{~m})$ scenarios was then linearly interpolated.

Land loss due to wave action is estimated using the mathematical definition of the Bruun Rule given in Hands (1983) as

$$
\mathrm{R}=\mathrm{G}\left[\mathrm{L} /\left(\mathrm{B}+\mathrm{d}_{*}\right)\right] \mathrm{S}
$$

where $\mathrm{R}$ is the shoreline retreat (erosion) due to a sea level rise $\mathrm{S}$ (scenario) above mean sea level, $\mathrm{d}_{*}$ is the depth of closure, $B$ is the dune/cliff height, $L$ is the width of the active profile, and $G$ is the inverse of the overfill ratio of the material being eroded. Fig. 2 shows the relationship of the parameters for the Bruun Rule. $\mathrm{G}$ can be safely taken to be 1 as sand is predominant on the open ocean coast of both study areas, and, hence, it is assumed that all the eroded material will remain within the active beach/near-shore profile. Where this assumption is not valid, some of the eroded material that is fine-grained (clay and silt) is lost to deeper water; so greater recession than reported would be expected.

$\mathrm{d}_{*}$ is determined using a range of techniques that include grain size trends, the orientation of offshore contours, and a wave-based approach. According to Nicholls et al. (1995), it is best to use the wave-based approach, as this can be directly related to time scale. Various studies conducted so far on the estimation of the potential impacts of sea level rise used the low and high estimates of closure depth, which, according to Nicholls et al. (1995), will embrace the actual depth of closure.

For the Gambian study area, $d_{*}$ is taken from Dennis et al. (1995) and assumed to be $d_{*(L, 1)}=3.4 \mathrm{~m}$ for the analysis of annual change and $d_{*(L, 100)}=5.9 \mathrm{~m}$ over a century. The depth of closure for the $100 \mathrm{yr}$ period was calculated from the annual depth of closure as:

$$
d_{*(L, 100)}=1.75 d_{*(L, 1)}
$$

where the coefficient (1.75) is based on Hands (1983).

$L$ was determined at different locations along the coast using bathymetric maps. Since the coastline of The Gambia shows varying beach width and dune and cliff heights, the Bruun Rule was applied to similar segments following the characterization of the coastline.

For the Abidjan Region of Côte d'Ivoire, the annual depth of closure $d_{*(L, 1)}$ was calculated using the wave methodology defined as:

$$
\mathrm{d}_{*(\mathrm{~L}, 1)}=2.28 \mathrm{H}-68.5\left(\mathrm{H}^{2} / \mathrm{gT}^{2}\right)
$$

where $\mathrm{H}$ is the annual exceeded wave height in a $12 \mathrm{~h}$ period, $\mathrm{T}$ is the associated wave period, and $\mathrm{g}$ is

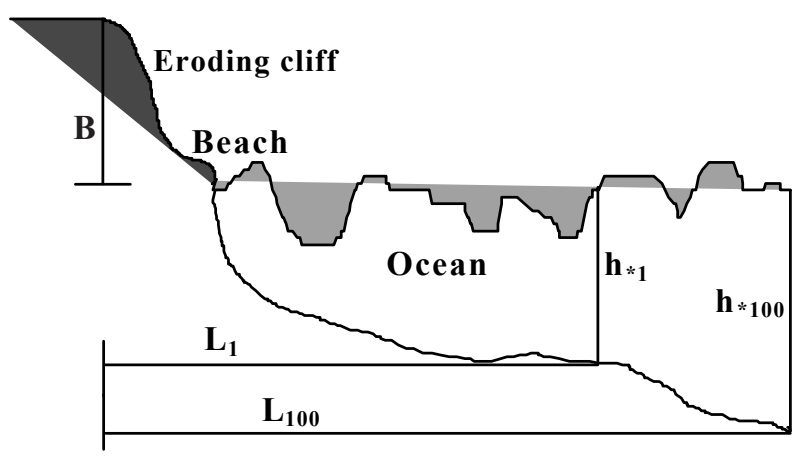

Fig. 2. Illustration of the Bruun Rule 
the acceleration of gravity. The value of $d_{*(L, 1)}$ was calculated for the various segments of the coast to which the wave data refer. The wave data were also obtained for 2 seasons and therefore $d_{*(L, 1)}$ was calculated for the seasons and then averaged to give $\mathrm{d}_{*(L, 1)}=2.84 \mathrm{~m}$ to represent the annual value. Using this annual depth of closure, $d_{*(L, 100)}$ was approximated to be $4.97 \mathrm{~m}$ using the relationship in Eq. (2), above.

It is worth mentioning here that a serious storm surge occurred in J uly 1984 that resulted in waves $3 \mathrm{~m}$ high at the Vridi Canal and $3.5 \mathrm{~m}$ high outside the Vridi Canal. Associated wave periods were 10.5 and $11.9 \mathrm{~s}$, respectively (Cissoko Souleymane, Côte d'Ivoire Oceanography Centre, pers. comm.). The annual and $100 \mathrm{yr}$ depths of closure for this rare event in Côte d'Ivoire were calculated as 6.28 and $10.99 \mathrm{~m}$, respectively, for the vicinity of the Vridi Canal, and 7.39 and $12.93 \mathrm{~m}$, respectively, for the area outside of the canal. No wonder there was a recorded loss of about $20 \mathrm{~m}$ of coastline around the canal (Abe 1993, as cited in Abe \& Lazare 1995) from this phenomenon.

2.2.4. Flooding and increase in groundwater levels: During the passage of West A frican disturbance lines (squall lines) in The Gambia, the accompanying heavy downpour causes flooding mostly in the capital city, settlements established on reclaimed land in dried-up valleys, and settlements that have been developed very close to mangrove swamps and wetlands. These are also the main areas where groundwater levels are close to the surface and saline intrusion in groundwater is already a problem. The areas most affected are the Half-die and Tobacco Road settlements in Banjul, parts of Bakau, Old J eswang, Eboe Town, Tallindiing, Fagikunda, and A buko.

The strength and frequency of tropical storms are expected to increase with the expected climate change. This will lead to more flooding, and the problem may be exacerbated with sea level rise. Damage to structures such as buildings and roads will be the major effect of the freshwater flooding.

2.2.5. Estimation of damage costs and population at risk: A comprehensive evaluation of the economic consequence of a $1 \mathrm{~m}$ sea level rise for both study areas was not possible due to inadequate data and limited resources. The evaluation was carried out only for some important zones of the study areas. The evaluation and analysis are based on socio-economic and demographic data collected during the study.

The costs of damage or loss to coastal infrastructure, such as roads, were also not evaluated. A quantitative assessment of wetlands was not possible, as these are not valued in monetary terms.
2.2.6. Limitations of the assessment: The study in Côte d'Ivoire was constrained by lack of data, particularly economic data. AVVA was not conducted, and characterization of the coastal zone was based on maps that are more than $10 \mathrm{yr}$ old. Even under such constraints, qualitative assessment has considerable value in addressing the possible impacts of sea level rise and climate change.

\section{RESULTS AND DISCUSSION}

\subsection{Land loss on the open coast}

In the coastal zones of The Gambia and the Abidjan region, about 92 and $563 \mathrm{~km}^{2}$, respectively, are estimated to be inundated as a result of a $1 \mathrm{~m}$ sea level rise (Table 1). The huge retreat of $563 \mathrm{~km}^{2}$ along the coastline of the Abidjan region is due to the fact that lowland marshes and lagoons dominate the coastal zone. For The Gambia, shoreline retreat would vary along the coast from $102 \mathrm{~m}$ in the harder cliffed zone between Cape St. M ary and Fajara to $839 \mathrm{~m}$ in the gently sloping, sandy strand plain near Sanyang Point (Table 2a). In the A bidjan region, average retreat due to coastal erosion is estimated as $51 \mathrm{~m}$ and varies from $36 \mathrm{~m}$ around the coast of Abidjan to $62 \mathrm{~m}$ on the GrandLahou coast (Table 2b).

Table 1. Potential area $\left(\mathrm{km}^{2}\right)$ of land to be inundated in the coastal zone of (a) The Gambia and (b) the Abidjan region in response to various sea level rise scenarios. Coastal units of The Gambia: Unit 1 =Senegal Border to Barra Point; Unit 2 = the Gambia River Basin; Unit 3 =Banjul Point to Cape St. Mary; Unit $4=$ Cape St. Mary to Fajara; Unit $5=$ Fajara to Bald Cape; Unit $6=$ Bald Cape to Solifor Point; Unit $7=$ Solifor Point to Benchmark KM 125; Unit $8=$ Benchmark KM 125 to Kartong Point; and Unit $9=$ Kartong Point to Allehein River

\begin{tabular}{|lrrrr|}
\hline \multirow{2}{*}{$\begin{array}{l}\text { Coastal } \\
\text { unit }\end{array}$} & \multicolumn{5}{c}{ Sea level rise scenarios (m century ${ }^{-1}$ ) } \\
& 0.2 & 0.5 & 1.0 & 2.0 \\
\hline (a) The G ambia & & & & \\
1 & 0.56 & 14.06 & 28.12 & 56.25 \\
2 & 0.94 & 23.40 & 46.87 & 93.75 \\
3 & 1.56 & 3.90 & 7.80 & 17.63 \\
4 & 0 & 0 & 0 & 0 \\
5 & 0.01 & 0.03 & 0.05 & 0.20 \\
6 & 0.41 & 1.01 & 2.03 & 2.89 \\
7 & 0.27 & 0.67 & 1.34 & 1.81 \\
8 & 0.03 & 0.08 & 0.17 & 0.17 \\
9 & 1.19 & 2.69 & 5.93 & 8.85 \\
Total & 4.96 & 45.89 & 92.32 & 181.55 \\
(b) A bidjan region & & & & \\
Grand-Bassam & 86.3 & 215.9 & 431.7 & 863.5 \\
A bidjan & 14.1 & 35.2 & 70.5 & 141.0 \\
Jaquesville & 1.9 & 4.9 & 9.7 & 19.5 \\
Grang-Lahou & 10.1 & 25.2 & 50.5 & 101.0 \\
Total & 112.5 & 281.3 & 562.5 & 1125.0 \\
\hline \multicolumn{5}{l}{} \\
\hline
\end{tabular}


Table 2. Application of the Bruun Rule to project land retreat and rate of beach erosion on the open coasts of (a) The Gambia and (b) the Abidjan region in response to a $1 \mathrm{~m}$ sea level rise. $d_{*}=$ depth of closure; $G=$ overfill ratio; $L=$ active profile width; $\mathrm{B}=$ dune or cliff height; $\mathrm{S}=$ scenario; $\mathrm{R}=$ retreat of land

\begin{tabular}{|c|c|c|c|c|c|c|c|}
\hline $\begin{array}{l}\text { Coastal } \\
\text { unit }\end{array}$ & $\begin{array}{r}\mathrm{d}_{*} \\
(\mathrm{~m})\end{array}$ & G & $\begin{array}{l}\text { M ap } \\
(\mathrm{cm})\end{array}$ & $\begin{array}{l}\text { L Actual } \\
\text { (m) }\end{array}$ & $\begin{array}{l}B \\
(\mathrm{~m})\end{array}$ & $\mathrm{S}$ & $\begin{array}{l}\mathrm{R} \\
(\mathrm{m})\end{array}$ \\
\hline \multicolumn{8}{|c|}{ (a) The G ambia } \\
\hline $\begin{array}{l}1 \\
2\end{array}$ & 5.9 & 1 & 3.5 & 2610.5 & 2.0 & 1 & 330.4 \\
\hline 3 & 5.9 & 1 & 3.0 & 2284.2 & 2.7 & 1 & 275.6 \\
\hline 4 & 5.9 & 1 & 1.6 & 1232.5 & 6.1 & 1 & 102.2 \\
\hline 5 & 5.9 & 1 & 2.8 & 2080.8 & 2.7 & 1 & 264.1 \\
\hline 6 & 5.9 & 1 & 8.6 & 6475.5 & 1.8 & 1 & 839.2 \\
\hline 7 & 5.9 & 1 & 6.8 & 5098.3 & 3.0 & 1 & 597.2 \\
\hline \multirow{2}{*}{\multicolumn{8}{|c|}{$\begin{array}{l}8 \\
9\end{array}$}} \\
\hline & & & & & & & \\
\hline \multicolumn{2}{|l|}{$\begin{array}{l}\text { Coastal } \\
\text { unit }\end{array}$} & $\begin{array}{l}d_{*} \\
(m)\end{array}$ & G & $\stackrel{\mathrm{L}}{\text { Actual (m) }}$ & $\begin{array}{l}B \\
(\mathrm{~m})\end{array}$ & $\mathrm{S}$ & $\begin{array}{c}R \\
(\mathrm{~m})\end{array}$ \\
\hline \multicolumn{8}{|c|}{ (b) Abidjan region } \\
\hline \multicolumn{2}{|c|}{ Grand-Bassam } & 4.97 & 1 & 372 & 2.0 & 1 & 53.1 \\
\hline \multicolumn{2}{|c|}{ Abidjan } & 4.97 & 1 & 238 & 1.6 & 1 & 35.6 \\
\hline \multicolumn{2}{|c|}{ J acqueville } & 4.97 & 1 & 380 & 2.0 & 1 & 54.4 \\
\hline \multicolumn{2}{|c|}{ Grand-Lahou } & 4.97 & 1 & 340 & 0.5 & 1 & 61.8 \\
\hline \multicolumn{2}{|c|}{ Average retreat } & & & & & & 51.2 \\
\hline
\end{tabular}

\subsection{Estimation of land loss on the sheltered coast}

In the sheltered coast of The Gambia, we consider only the low-lying mangrove systems and adjacent marshland and agricultural lowlands. These systems extend to about $200 \mathrm{~km}$ from the mouth of the river, and hence wave action is not critical. As shown in Table la (Unit 2), about $50 \%\left(47 \mathrm{~km}^{2}\right)$ of the total land loss due to inundation comes from the sheltered coast.

The effects of sea level rise on mangroves depend on the extent to which the mangroves continue to receive sediment. Where there is little or no sediment supply, submergence is likely to cause dieback and erosion of their seaward margins. In a natural environment, mangroves can still spread landward, displacing the low-lying hinterland. However, the mangrove systems bordering Banjul, Bakau, Old J eswang, Eboe Town, Talinding Kunjang, Fajikunda, and Abuko have all their hinterland reclaimed for settlements, and thus the mangrove fringe and the adjacent agricultural lands have become narrower and will eventually disappear as the sea level rises. This will lead to a loss of a large area of wetlands and fish spawning grounds.

\subsection{Flooding and increase in groundwater levels}

Heavy downpours of rain that accompany squall lines during the wet season cause flooding in the capi- tal city, settlements established on reclaimed land in dried-up valleys, and settlements close to mangrove swamps and wetlands. With an increase in strength and frequency of tropical storms under a warmer climate, this phenomenon will increase. The problem may further be exacerbated by sea level rise.

Only a small percentage of the population in the areas obtain their water supply from local, shallow hand-dug wells. The higher water table due to sea level rise will exacerbate the existing problems of salinization of the water supply. This situation is similar to that in the settlements surrounding the city of A bidjan due to the presence of lagoons.

\subsection{Estimates of damage costs and population at risk}

With a $1 \mathrm{~m}$ sea level rise, it is evident that the whole of Banjul, the capital city of The Gambia, will be lost because the greater part of the city is below $1 \mathrm{~m}$ above sea level, as shown in Fig. 3. The mangrove systems on St. Mary's Island, Kombo St. Mary, and the strand plains in the north bank from Barra to Buniadu Point will be lost.

The entire population of Banjul (42000 inhabitants), people living in the eastern parts of Bakau and Cape St. M ary, and the swampy parts of Old J eswang, Kanifing Industrial Estate, Eboe Town, Tallinding Kunjang, Fagikunda, and Abuko will be displaced. A bout 1950 billion Dalasis (US $\$ 217$ million) worth of land will be lost. All the structures located on the land area from Sarro to the Banjul cemeteries will be lost.

Although some important areas of Abidjan lie on a plateau and may escape the direct effects of a $1 \mathrm{~m}$ sea level rise, major economic centres of the region, such as the Port of Abidjan and the international airport at Port Bouet, will be severely affected as most of the land is equal to or less than $1 \mathrm{~m}$ above sea level. The element of the infrastructure that is most threatened is the Autonomous Port of Abidjan (Port Autonome d'A bidjan, PAA), which contributes more than $68 \%$ of the importation into and $60 \%$ of the exportation from the country (PAA 1996). It has about $5 \mathrm{~km}$ of quays (29 quays); 28 depots for goods; 11 other specialized depots for fertilizer, phosphates, and hydrocarbons; a container terminal for fruits, vegetables, timber, and oil; a fisheries port; and so forth. PAA has over $140000 \mathrm{~m}^{2}$ of hangers and stores, 770 ha of industrial zone, and over $360000 \mathrm{~m}^{2}$ of terraces.

This entire infrastructure is currently threatened by an erosion rate of about $2.4 \mathrm{~m}$ annum ${ }^{-1}$, and when the sea level rises by $1 \mathrm{~m}$ within the next century most of the area will be inundated. This inundation will be followed by a retreat of the land by another $11.5 \mathrm{~m}$ due to erosion to the east of the Vridi Canal. The present 


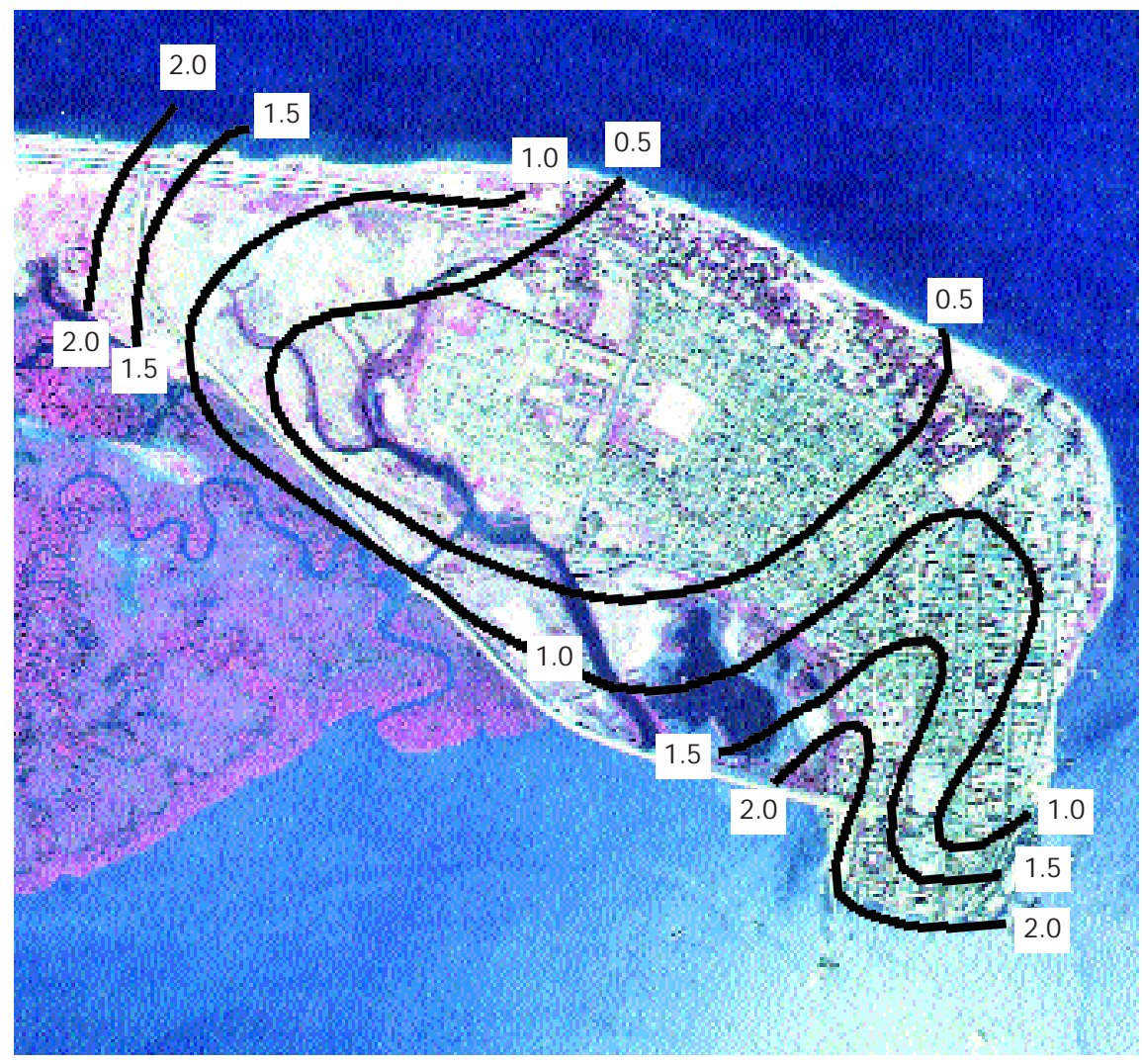

Fig. 3. Orthophoto map of the city of Banjul (the greater part of the city is below $1 \mathrm{~m}$ ) ven into the beach and tied together with timber. They are also constructed from reinforced concrete, as on the Maputo shoreline in Mozambique. They are easy to build, are fairly cost effective, and locally hold the beach or capture more sand in the longshore sediment transport (LST) system. They do not 'create' new sand but merely redistribute the sand along the beach. Groins have been found to be very effective in stabilizing eroded beaches particularly in the Republic of Togo, West Africa (Blivi 1993).

This response strategy is recommended for the coast of the Abidjan region, particularly east of the Vridi Canal. In The Gambia, the existing groins in the area between the Laguna Beach/Palm Grove hotels and Banjul Point (Fig. 4) need to be rehabilitated. To reduce the flow of sand to the port and ferry terminal, a long and high terminal groin must be constructed at Banjul Point. This terminal groin must not be filled

erosion rate is due mainly to the construction of moles on both sides of the canal and a breakwater on the western flank of the canal. This breakwater traps most of the longshore sand coming from the west. This has led to an accretion rate of 2.3 and $4.6 \mathrm{~m}_{\text {annum }}{ }^{-1}$ between 1975 and 1985 and between 1985 and 1996, respectively, on the western side of the canal.

\section{RESPON SE STRATEGIES AND ADAPTATION OPTIONS}

\subsection{Response strategies}

In both study areas, the suggested response is to protect only the important areas. For The Gambia, these are the areas between Banjul and Cape Point and areas around the hotel complex from Kairaba to Kololi Beach Hotel. For the Abidjan region, the important areas are the major cities of Grand-Lahou, Abidjan, and Grand-Bassam. The following shoreline hardening and stabilization techniques could be used to protect these area.

Groins are a major technique of beach stabilization in Africa, whereby trunks of rhun palm trees are dri- with sand so that the longshore sediment transport is halted or reduced for some period of time.

Another shoreline stabilization technique that could be useful in the protection of the sandy beaches of The Gambia and the Abidjan region is the breakwater system (Fig. 5). Breakwater systems have the ability to reduce the strength of breaking waves coming onshore, reduce the impact of waves on the shoreline, and thus reduce the quantity of sand eroded.

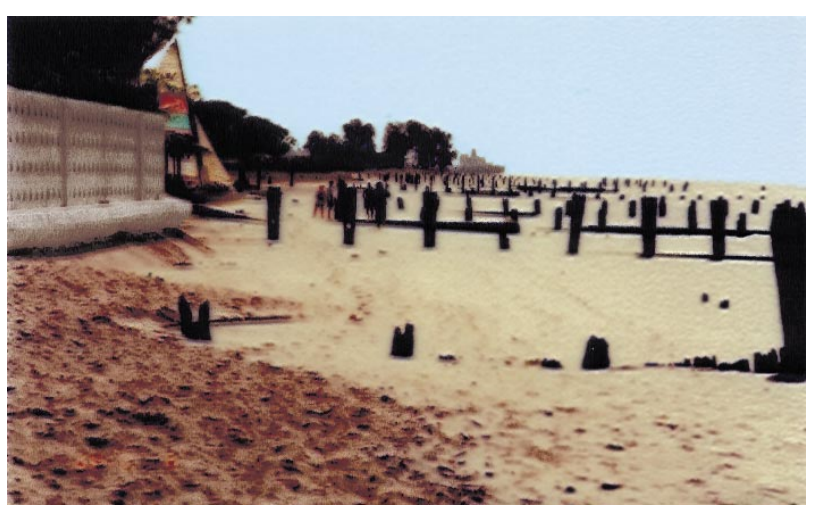

Fig. 4. Damaged groin system that has protected the City of Banjul for more than $40 \mathrm{yr}$ 


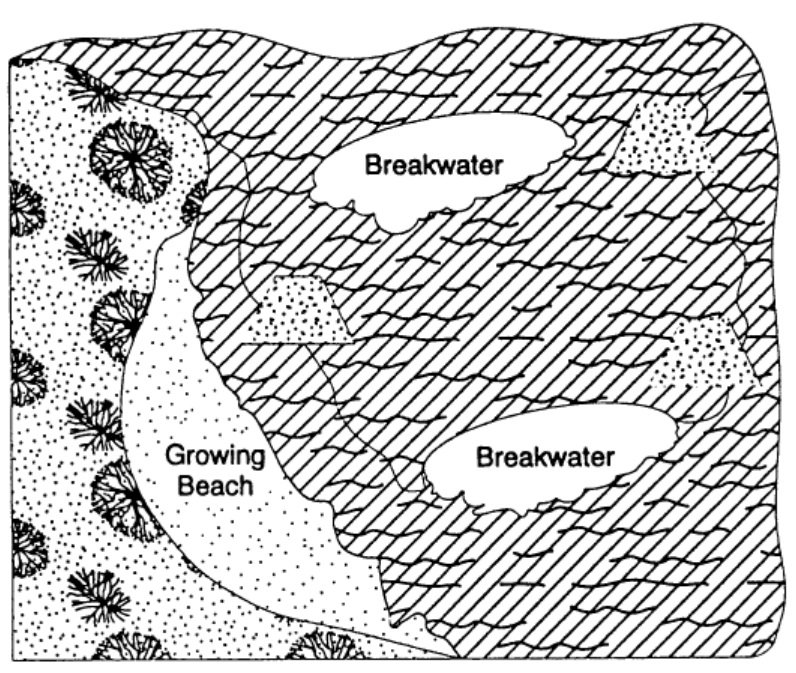

Fig. 5. Breakwater system for reduction of erosive wave energy

Revetments are also useful in reducing erosion but need proper construction to be effective. They are expensive, and in most cases the beach is lost. Revetments consist of a layer of large boulders on the seaward side and a layer of filter screening material on the landward side. Theses 2 layers are separated by another layer of medium-size gravel that is used to protect the screening material (Fig. 6). The voids in the structure of the outer layer on the seaward side are used to dissipate wave energy; the filter screening material of the landward layer allows water to pass through. It may be sufficient to build only a low-cost seawall or a bulkhead.

Particularly for The Gambia, it may be necessary to employ an innovative sand management approach to solve the large erosion problem between the NAWEC (National Water and Electricity Corporation) water tanks and Banjul Point. This could be achieved by tying the end of the sand spit off the Palm GroveLaguna Beach hotel complex (Fig. 7) to the mainland so that it becomes a sand-feed to the area to the east

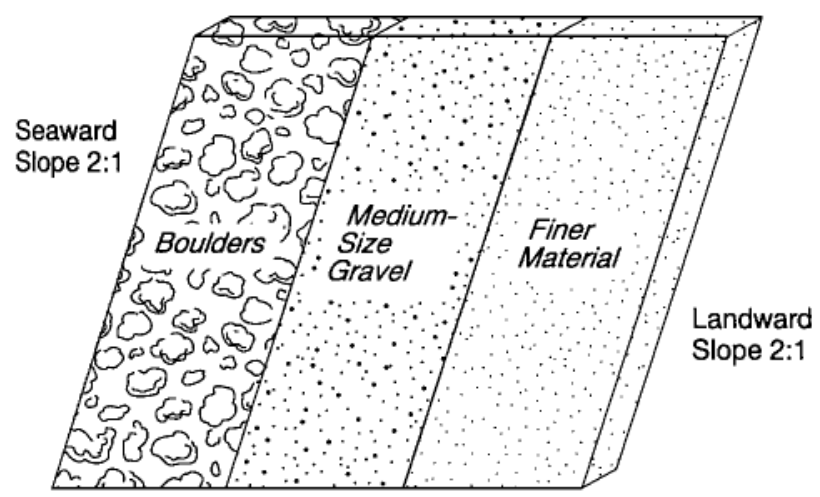

Fig. 6. Cross-section of a revetment and the city of Banjul. This would, however, result in the flow of a large unwanted quantity of sand to the Banjul-Barra ferry terminal and the Gambia Ports Authority facilities, the solution to which is suggested above-that is, constructing a long terminal groin at Banjul Point.

Also, to protect the area between the cold storage plants west of the Public Works Complex (National Partnership Enterprise and Pelican) and the Gambia Senior Secondary School, and areas bordering the mangrove systems, it is sufficient to use dikes made up of about 1.5 to $2 \mathrm{~m}$ of sand on which some vegetation is planted.

\subsection{Adaptation options}

\subsubsection{Public awareness and outreach activities}

These activities would inform the public of the danger of living in coastal lowlands that are at risk of being affected by sea level rise. Timely public education about sea level rise impacts and risks could be a costeffective means of reducing future expenditure.

\subsubsection{Increase in height of coastal infrastructure and urban growth planning}

Physical planning and building control measures and regulations should be instituted and implemented. The land, physical planning, and building control institutions of The Gambia and the Abidjan region should

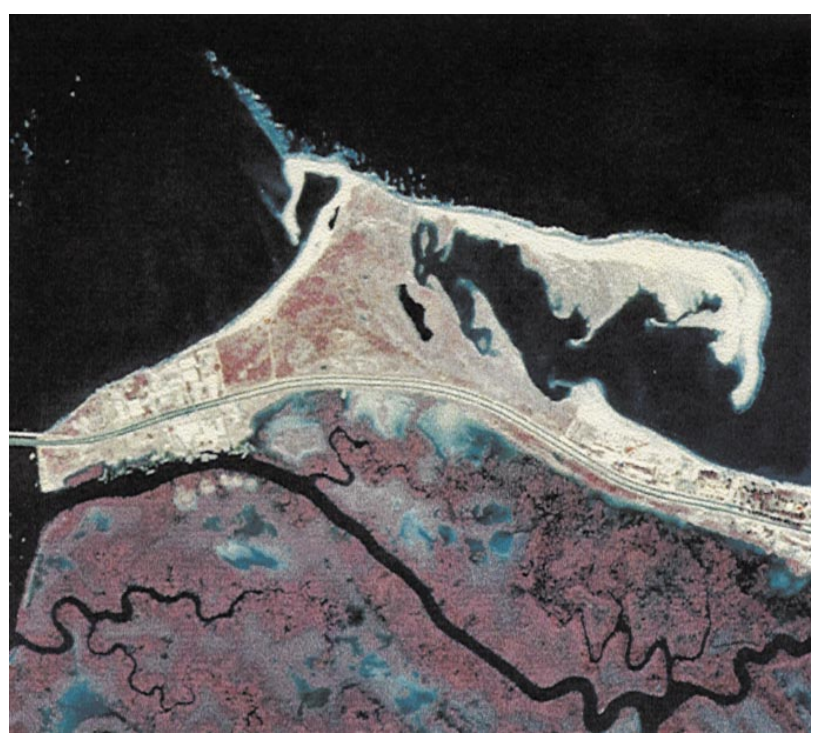

Fig. 7. Sand spit at the Palm Grove/Laguna Beach Hotel complex 
avoid allocation of land that is likely to be flooded, such as the dried-up streams on the Kombo Peninsula, which have recently witnessed flooding during the rainy seasons of the late 1980s and the lagoon areas of Abidjan.

Where the building of coastal infrastructure such as roads, fish landing sites, and curing plants are approved and must be put in place, the authorities and owners of these infrastructure elements should make sure that marginal increases in the height of the structures are included to account for sea level rise and any other related phenomena. Siting of large capital facilities or those that pose significant hazards when flooded should not be allowed in sensitive lands and must be directed toward less vulnerable areas. People located in high-risk areas should be offered incentives to relocate out of these areas. Policies should be instituted that allow the use of high-risk areas as natural preserves or for low-value use.

Marginal increases in the height of the infrastructure elements during construction phase and redirecting growth away from sensitive lands are relatively inexpensive options for reducing the impacts of sea level rise and risks of flooding. Policies that may lead to relocation from high-risk areas will reduce the need and cost of disaster relief in the future.

\subsubsection{Wetland preservation and mitigation}

The estuary of the River Gambia and lagoons of the Abidjan region contain economically important wetlands and mangrove systems. The mangrove systems on the Kombo St. M ary Island and Kombo Peninsula are important breeding grounds for various aquatic species. Efforts should be made to protect these areas by declaring them protected wetlands. This would discourage exploitation of the resources in these wetlands. The possible impacts of upstream dams on the River Gambia in terms of reduced sediment supply should be investigated.

\subsubsection{Coastal zone management plan}

Land-use planning in coastal zones, such as using building setbacks or allocating low-lying vulnerable lands to lower value uses (for example, parks rather than housing), will help reduce the overall vulnerability to sea level rise. Other land use planning mecha- nisms, such as construction standards, reduce the risks of living in coastal areas. Additional risk-reduction measures can be encouraged through appropriate financial mechanisms. Each of these policies reduces the risks from current climatic variability and protects against potential sea level rise impacts. When put together in the form of a programme, they constitute a coastal zone management plan.

Acknowledgements. This study was funded by the US Country Studies Program (USCSP). Mr Robert K. Dixon is the Program Director and Ms Sandy Guill is the Project Officer for The Gambia and Africa. Presentation at the workshop was made possible through the funding from the United Nations Environment Programme (UNEP), the Netherlands Climate Change Studies Assistant Programme, and the USCSP.

\section{LITERATURE CITED}

Abe J , Lazare N (1995) Vulnerabilite du littoral Ivoirien aux changements climatiques et a l'elevation du niveau de la mer. Paper presented at the Atelier sur la Gestion Intergree des Zones Littorales. CERESCOR, Guinea, 3 to 9 December 1995

Blivi A (1993) M orphology and current dynamic of the coast of Togo. In: Coastlines of Western Africa.

Delor C, Diaby I, Yao B (1992) Notice explicative de la cartegeologique feuille Grand Bassam. Iere Edition, M emoire 4

Dennis KC, Niang-Diop I, Nicolls RJ (1995) Sea level rise and Senegal: potential impacts and consequences. J Coastal Res Spec Issue 14:243-261

Hands EB (1983) The Great Lakes as a test model for profile response to sea level rise changes. In: Komar PD (ed) $\mathrm{Handbook}$ of coastal processes and erosion. CRC Press, Boca Raton, $p$ 167-189

IPCC (Intergovernmental Panel on Climate Change) (1990) Response strategies and adaptation assessment. Report of Working Group III of the IPCC. Cambridge University Press, Cambridge

J allow BP, Barrow MKA, Leatherman SP (1996) Vulnerability of the coastal zone of The Gambia to sea level rise and development of response options. Clim Res 6: 165-177

Leatherman SP, Nicholls RJ, Dennis KC (1995) Aerial videotape-assisted vulnerability analysis: a cost- effective approach to assess sea level rise impact. J Coastal Res Spec Issue 14:15-25

Nicholls RJ, Leatherman SP, Dennis KC, Volonte CR (1995) Impacts and responses to sea level rise: qualitative and quantitative assessments. J Coastal Res Spec Issue 14: 26-43

PAA (Port Autnome d'A bidjan) (1996) Port Autonome d'A bidjan-une reference en Afrique. Vridi Les Merees 1995, Abidjan

Pepper W, Leggett J , Swart R, Wasson J , Edmonds J , Mintzer I (1992) Emissions scenarios for the IPCC update: assumptions, methodology, and result

Quelennec RE (1988) Identification of coastal erosion problems in The Gambia. UNEP Report 